\title{
The Factors Effecting Employee Commitment to Change in Public Sector: Evidence from Yemen
}

\author{
Hamid Mahmood Gelaidan ${ }^{1} \&$ Hartini Ahmad ${ }^{1}$ \\ ${ }^{1}$ School of business management, College of Business, University Utara Malaysia, Sintok, Kedah, Malaysia \\ Correspondence: Hamid Mahmood Gelaidan, School of business management, College of Business, University \\ Utara Malaysia, Sintok, 06010, Kedah, Malaysia. Tel: 60-4-928-6676. E-mail: hamid.mahmood@uum.edu.my
}

Received: October 29, 2012

Accepted: December 6, 2012

Online Published: January 25, 2013

doi:10.5539/ibr.v6n3p75

URL: http://dx.doi.org/10.5539/ibr.v6n3p75

\begin{abstract}
This study attempted to investigate the moderating effect of organizational culture between the leadership style and normative commitment to change. The study relied on the data collected from 371 employees of Yemeni public sector. The finding of this study shows that organizational culture plays an important role of moderating the relationship between leadership style either transformational or transactional and normative commitment to change. Furthermore, the results light out that the transformational leadership is positively related with normative commitment to change. In the same line, transactional leadership is found to be not only positively related with normative commitment to change but also as stronger effect on it. This study was carried out with numerous limitations as example is cross sectional was conducted in this study and this could not figure out the effect pre and after change, thus longitude study is highly recommend in order to look in deep and compare the result. Not only this but also there may conduce in another sector and industry, it may come out with different light. With believing of different culture and its effect, future study can be conducted in different research context. This research has figured out the weakness of empirical study in change management literatures by connecting the leadership style, and organizational culture, and how they are associated to employee normative commitment to change. In the same way, it has provided a guideline for the public sectors in general and particularly in Yemen context on how to successfully implement change phenomena as well as how to get effective and efficient leadership with change management.
\end{abstract}

Keywords: leadership, commitment to change, change management, organizational culture, Yemen

\section{Introduction}

Change is a phenomenon that individuals and organizations face on a daily basis (Battilana, Gilmartin, Sengul, Pache, \& Alexander, 2010 ). Organizations have to respond quickly to the global forces since they are immersed in a virtual tempest of change regardless of their nature of business (Burke, 2002; Lo, Ramayah, de Run, \& Voon, 2009; Westover, 2010). This is because organizations need to strive to adapt to the ever increasing challenges of both their domestic and global markets (Herold, Fedor, Caldwell, \& Liu, 2008; Martins, 2008) Consequently, in order to respond to demands placed on them by their external environments and complex value chain activities, a variety of changes in any organization should take place such as process reengineering, continuous improvements, restructuring, downsizing and rightsizing, merger and acquisition (H. Ahmad, Francis, \& Zairi, 2007; Kavanagh \& Ashkanasy, 2006; Martins, 2008). (Herold, Fedor, \& Caldwell, 2007) pointed out that, leadership and organizational change are very important elements of study for researchers and practitioners. This study presents the significance of combining these two areas of study. This view is supported by (Bernard M. Bass, 1985; B.M. Bass \& Riggio, 2006; Battilana, et al., 2010; John P. Kotter, 1995). Notably, one of the many reasons why change efforts failed have been argued to lies in humans and their inadequate or lack of commitment to change (Elias, 2009). The current researcher observes that when there is commitment from people in the organization, the change is more likely to happen smoothly. This view is supported by studies such as (Shum, Bove, \& Seigyoung, 2008) and (Svensen, Neset, \& Eriksen, 2007). (Elias, 2009) stressed that failure of the change mostly came from the human aspect. Furthermore, (John P. Meyer, Srinivas, Lal, \& Topolnytsky, 2007) and (Conway \& Monks, 2008) argued that no organization can impose change if its employees are not showing acceptance of the change. In line with this, we observe that change will not be effective and valid if employees are not involved in the effort and the successful change would not be possible without people 
changing themselves. It is believed that organizational change is a challenge that all organizations encounter. Therefore, the study further states that while change can be managed externally, it would only be implemented when employees accept the change internally and this is supported by some recent studies such as (John P. Meyer, et al., 2007), (Conway \& Monks, 2008), (Howarth \& Rafferty, 2009) and (Lo, Ramayah, \& Run, 2010). It is valuable of this study to verify if leadership theory and commitment to change are applicable in the public sector in least developed country particularly in Yemen. With aforementioned purpose, the questions that are to be highlight in this study are: (1) Is there a significant relationship between leadership style such as transformational and transactional leadership and employee normative commitment to change? (2) Is organizational culture significantly moderating the relationship between leadership style (transformational and transactional) and normative commitment to change?

\section{Background of Public Sector Reform in Yemen}

Nowadays, the rapidly change has driven the organizations to reform regardless of nature of their business, be it is public or private. Thus, Yemen public sector has realized the impertinence of change management, and the government has started its first step by early 1990 especially after north and south Yemen reunited. Along the way, many challenges have raised from time to time. Because of the civil war which occurred in 1993, the train of change has been stopped for a couple of years. Consequently, the government has resumed the change phenomena of organization by doing restructuring, reform, rightsizing, reengineering, merger and acquisition, downsizing, decentralization, new technology system and new machine. In sum of that, in the early 1997, the Yemeni government lunched the biggest phenomena of change namely Financial and administrative reform with the supporting from The World Bank. Financial and Accounting Management Information System (AFMIS) is one result of that change and it has been dealt as a sample target of this study. It was launched in 2007, and had been implemented in four ministries as the first stage followed by all public sectors as a final stage. The main objective of this change was to enhance efficiency and effectiveness of public sector as well as to reduce the huge number of corruption, which lead to deliver such good service to the public and to the country. Although this was a great effort to be done from government side, but it was not sufficient to pick up the public sector organization to be effective and efficient as well, because the government has not paid adequate attention to the key factor of successful change which are the people.

The employees of public sector in Yemeni organization were getting low income with high job dissatisfaction, a low empowerment, low job justice, involvement, readiness of change, and insecurity that is lead to not fulfill their needs, that is really harm supporting the change and development process not only among the followers but also among the leaders as well. In addition, the corruption was widespread among the organizations and Yemen government was considered as one of the highly corrupted in the world. This also added as serious barrier to change and development. Aforementioned, one of the critical factors of failure to change is the people support. In line with this (Ahmad \& Gelaidan, 2011) indicted that many barriers has faced the change and development of Yemeni organization and conclude that of people, whether the leaders or the followers support. Due to that, this study is response the emergence call to find out how leadership can enhance the normative commitment to change and how the organizational culture can enhance the relationship between the leadership style and employee's normative commitment to change.

\section{Literature Review and Theoretical Framework}

(John P. Meyer, et al., 2007) indicated that the organizations have to respond quickly to the call of changing environmental forces in order to be survive and thrive in rapidly change current market. (John P. Kotter, 1995) indicated that organizational change is ultimately the people process and with climate being the people's perception of the organization, transformational leadership style may be the most effective leadership style in times of change which suggests that the transformational leadership style may finally be of more value in helping leaders lead organizational change by enhancing the commitment to change among the employees. Therefore, in the context of organizational change, there is a disagreement over which model can be in use in the organizational change as various researchers have discussed organizational change in a variety of aspects and found many approaches and finally, researchers came out with two main approaches toward organizational change, rarely the planned change approach and the emergent change approach (Burnes, 2004). Planned change initiative can solve problems faced by organizations which arise from the consequence of dissatisfaction with the status quo. (Argyris \& Schon, 1978) pointed out that planned change essentially leads to minor surface change such as leaving organizational assumptions, values and beliefs which are unidentified. Therefore, this model has been used by a number of researchers to help practitioners make successful implementation of the change. (Argyris \& Schon, 1978) found out that radical change model is used to change organisational style when culture change is essential. However, the incremental change model only focuses on developing the existing system and 
continues within the current business model. Both models have the tendency to unfreeze current behaviour, change current behaviour and refreeze new behaviour. The current researcher refers to the planned change approach because it is in accordance with the research setting. In this context, (J. P. Kotter, 1996) suggests that in order to make a successful change some preliminary conditions should be satisfied. For example, high commitment from the employee and the leader is required to enhance the change. Moreover, he stated: "Producing change is about 80 percent leadership build up direction, aligning, motivating and inspiring people and about 20 percent management (planning, budgeting, organizing, and problem solving)".

\subsection{Employee Commitment to Change}

Employee commitment to change is defined as "a force (mind-set) that binds an individual to a course of action deemed necessary for the successful implementation of a change initiative" (Herscovitch \& Meyer, 2002). (Porter, Steers, Mowday, \& Boulian, 1974) declared that, commitment could be classified into three factors as (i) a strong belief and acceptance of the organization's goals and values, (ii) a willingness to exert considerable effort on behalf of the organization and (iii) a definite desire to keep organizational membership. Further research on these components has shown that any one of the three components is sufficient to produce the desired behaviour (J.P. Meyer \& Allen, 1997; J. P Meyer \& Herscovitch, 2001). While there are relatively few studies employing (Herscovitch \& Meyer, 2002) construct of commitment to change, such as (Cunningham, 2006), Conway and Monks (2008), Herold et al. (2008) and (Parish, Cadwallader, \& Busch, 2008). However, (Herscovitch \& Meyer, 2002) conducted three studies to validate a model of commitment that is specific to organizational change. They defined commitment to change as aforementioned a force (mindset) that binds an individual to a course of action deemed necessary for the successful implementation of a change initiative (Herscovitch \& Meyer, 2002). The findings of their studies established that the measure of commitment to change was actually referring to the three-component model and each of the three components was distinguishable from the other and from the components of organizational commitment. In further work, (Herscovitch \& Meyer, 2002) has developed an instrument specifically designed to measure commitment to organizational change. Even though, there are three component of employee's commitment to change is three which are affective, continues and normative, only normative commitment to change will be discussed in depth because it is the main concern of this study.

Normative commitment to change is considered as an "ought to" which senses the obligation to provide support for the change (J. P Meyer \& Herscovitch, 2001). This sort of commitment deals with the obligation an individual feels to be committed to a course of action. An individual with high normative commitment will feel that he/she ought to be committed. Meyer and Allen (1991) proposed that normative commitment develops through socialization and internalization of norms, or when an individual receives benefits and feels a need to reciprocate. Additionally, this type of organizational commitment to change is important particularly in this context. Cunningham (2006) conducted researches in United States by examining the relationship among commitment to change, coping with change and turnover intentions. Data were collected from 299 employees of 10 organizations undergoing significant organizational change. He found that normative commitment to change had a direct impact on turnover intentions. Meanwhile, (Herscovitch \& Meyer, 2002) found validity evidence for a three-component model of commitment to change, as well as support for the linkage between commitment to change and subsequent behaviors associated with supporting change. However, (Cunningham, 2006) indicated that, despite the noted importance of commitment to organizational change, little research systematically attempting to measure the construct, its antecedents, and its outcomes were minimum. Thus, this study attempts to examine the leadership style effect which is considered as one of the most important factors that can affect the employee commitment to change. (Parish, et al., 2008) examined the antecedents and the consequence of the employee commitment to change. They found that all antecedents (fit with vision, employee manager relationship quality, job motivation and role autonomy) influence commitment to change. They recommended further research in this field adding other antecedents to commitment to change which could include like, organizational culture, and/or leadership style. With respect to the previous study, the ambiguity of the gap between the leadership style and commitment to change and organizational culture still existed. Therefore, this study attempts to respond to the call by examining the relationship between the leadership style and employee commitment to change without neglecting the effect of the organizational culture, which is plays an important role in moderating the relationship among the leadership style and employee commitment (Yiing \& Ahmad, 2009).

\subsection{Transformational Leadership}

Transformational leadership is the style of leadership that leads to positive change by always being energetic, enthusiastic and encouraging followers to look for new ways to achieve their objectives. (Bernard M. Bass, 
1985) original conceptualization of transformational leadership has its basis on the interaction of the three factors of charisma, individualized consideration and intellectual stimulation (Bycio, Hackett, \& Allen, 1995) ever since then, these factors have gradually changed (B. M. Bass \& Avolio, 1994) to idealized influence, inspirational motivation, intellectual stimulation and individualized consideration; all represent the effectiveness of transformational leadership. (Ismail, Mohamad, Mohamed, Rafiuddin, \& Zhen, 2010) examined the relationship between transformational and transactional leadership styles and individual outcomes (i.e., perceptions of justice and trust in the leaders), the result based on 118 employees who have worked in a United States subsidiary firm in East Malaysia. The authors found that transformational leadership is an important predictor of procedural justice whereas transactional leadership is an important predictor of distributive justice, and both leadership styles are important predictors of trust in the leaders.However, transformational leaders greatly influence all aspects of the organizational cultures they operate in, an indication of their expected influence on employees' commitment to change. It is suggested that regardless of the commitment target (e.g. organization, career, occupation and organizational change) basic processes are involved in the development of affective, continuance and normative commitment (J. P Meyer \& Herscovitch, 2001). Normative commitment is developed when individuals receive benefits that make them need to reciprocate. If these techniques of commitment formation are applicable to the context of organizational change, it is reasonable to be expecting transformational leadership to have positive effects on normative commitment to change. Following research hypotheses is tested:

\subsection{Transactional Leadership}

Transactional leadership style conveys a functional, practical leader-follower relationship that is important to facilitate the exchange of valued resources or satisfying needs. (Burns, 1978) explains that these transactional leader-follower relationships are based on cost-benefit concerns whereby leaders concentrate on brokering transactions comprising of mutual promises and rewards. This type of leadership style is mainly concerned with the exchange of one thing for another in a relationship where an individual's needs are met in the form of reward on the condition that the work objectives provided by the leader are successfully achieved. (Bruce J. Avolio \& Bass, 2002) suggested that contingent reward is reasonably effective, though not as effective as the transformational components in motivating others to achieve higher performance levels. They also argued that management by exception tends to be ineffective, but in some situations, it may be suitable. In relation to employee response to change initiatives, a study of leadership effect on Total Quality Management (TQM), behaviours and policies suggested that management by exception leadership behaviours are likely to result in hesitation on the part of the followers to take risks associated with change efforts or other improvement initiatives (Sosik \& Dionne, 1997). Obviously, transactional leadership has significant relationship with normative employee commitment to change.

\subsection{Organizational Culture}

Organizational culture is generally seen as a set of key values, assumptions, understandings, and norms that is shared by members of an organization and taught to new members as correct (Hofstede, 2005). Member of an organization are always concerned with what the organization actually needs and wants from them in order to be effective members of the organization. (Martin, 2002) defined that, culture is a way of learning everyday life in the organization and he recommended three traditions of organizational culture which are: (i) the integration perspective which assumes that people in the culture share a common set of values or a common set of norms. This statement may come out in the mission, logo and uniform; (ii) the perspective of differentiation which takes into account the fact that organizations contain people who come from different social and ethnic backgrounds and subcultures may exist; and (iii) the third tradition is the fragmentation perspective. Thus, understanding organizational culture is very crucial in order to implement any change smoothly and therefore, this study seeks to establish the essential role that organizational culture plays in the relationship between the leadership style and employee commitment to change. There is evidence in past literatures that organizational culture is directly linked to employee attitudes and behaviour and it is important in order to ensure the success of organizational change (K. Vestal, Fralicx, \& Spreier, 1997). To add on this to explanation, (Ahmad \& Gelaidan, 2011) found that organizational culture moderated the relationship between the leadership style and employee commitment to change particularly affective commitment to change, and they highly recommend to moderated the relation with the other two of commitment to change continues and normative. Another study conducted in Taiwan has a similar result whereby (Silverthorne, 2004) found that organizations dominated by the bureaucratic organizational culture showed the lowest level of organizational commitment, the innovative culture reflected a middle level of commitment and the supportive culture showed the highest level of organizational commitment. According to (John P. Meyer, Stanley, Herscovitch, \& Topolnytsky, 2002) developing a supportive work environment and gaining employee commitment early in the change process given a better chance to gaining 
long-term commitment during the change. Therefore, understanding the relationship between culture and employee behaviour plays a crucial role in developing effective interventions in order to guide change processes. Studies have also shown that making large-scale change permanent in the long term is very difficult (Huq \& Martin, 2001; Narine \& Persaud, 2003) and this can only be done by ensuring that the desired behaviours are consistent with the culture of the organization (Narine \& Persaud, 2003; Neuhauser, 1999). Thus, resistance to change can occur when the proposed change is seen to be inconsistent with current cultural norms and beliefs (K. W. Vestal \& Fralicx, 1997).

\subsection{Hypotheses and the Research Model}

Based on the earlier literature, the model of this research was devised (see figure 1). Three hypotheses were proposed. (H1) proposed the relationship between transformational and employee normative commitment to change. (H2) proposed the relationship between transactional and employee normative commitment to change. Finally, (H3) proposed the moderating effect of organizational culture between transformational leadership and normative commitment to change. (H4) proposed the moderating effect of organizational culture between transactional leadership and normative commitment to change.

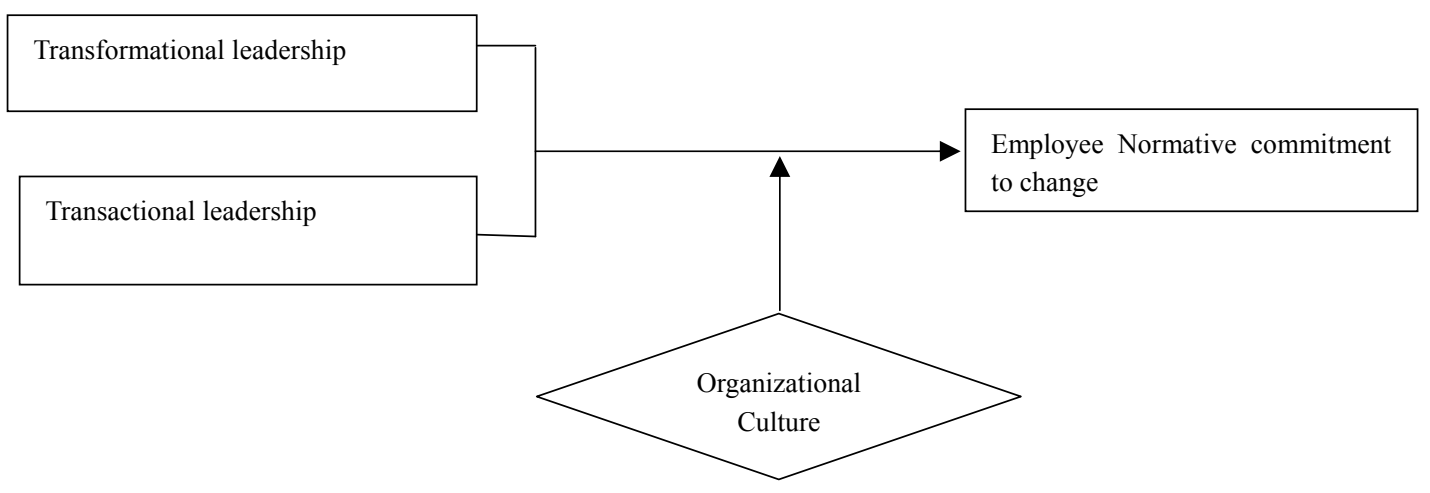

Figure 1. The research model

H1: There is a significant relationship between transformational leadership and employee's normative commitment to change.

$\mathrm{H} 2$ : There is a significant relationship between transactional leadership and employee's normative commitment to change.

H3: Organizational culture moderates the relationship between transformational leadership and employee commitment to change such as normative commitment to change.

H4: Organizational culture moderates the relationship between transactional leadership and employee commitment to change such as normative commitment to change.

\section{Method}

\subsection{Respondent's Profiles}

Respondent's profiles describe the demographic profiles including ministry, tenureship, gender, age, and education level (see Table 1). Most of the respondents were from the Ministry of Finance and Ministry of Public Work and Highway (51.2\%), with tenureship between 6-10 years (32\%), with majority of respondents were males $289(77.9 \%)$ and age between $40-49$ (32.9\&), and were the vast majority being Bachelor's degree holder $212(57.1 \%)$.

\subsection{Population and Sample Size}

The study was conducted to examine the relationship between the leadership style and employee normative commitment to change as well as to examine the moderating effect of organizational culture in Yemen public sector context. The population of the study was the employees in Yemen's public sector. Due to the large number of employees, the expertise in statistic have provide clear elaboration and stated what the accurate sample size for each number of population, such as (Krejcie \& Morgan, 1970) recommended for more than one million population, the accurate sample size is 384 which have been used in this study. The researcher have followed this recommendation, and distributed duplicated the recommended sample size (786) due to the poor culture research and avoiding low respond rate. Even thought, the responded rate was $51 \%$ and 402 questionnaire collected back. 
Out of 402 responded 20 were have missing value and about 11 were outlier which deducted by using mahalanobis technique. In that case, the valid number is 371 which used for further analysis.

Table 1. Respondents' profile

\begin{tabular}{|c|c|c|c|}
\hline Demographic & & Frequency & Percent (\%) \\
\hline \multirow[t]{4}{*}{ Ministry } & Ministry of Finance & 95 & 25.6 \\
\hline & Ministry of Public work and Highway & 95 & 25.6 \\
\hline & Ministry of Public Health and Population & 92 & 24.8 \\
\hline & Ministry of Education & 89 & 24.0 \\
\hline \multirow[t]{4}{*}{ Tenureship } & $1-5$ years & 76 & 20.5 \\
\hline & $6-10$ years & 122 & 32.9 \\
\hline & $11-15$ years & 95 & 25.6 \\
\hline & 16 above & 78 & 21.0 \\
\hline \multirow[t]{2}{*}{ Gender } & Male & 289 & 77.9 \\
\hline & Female & 82 & 22.1 \\
\hline \multirow[t]{4}{*}{ Age } & $20-29$ years & 53 & 14.3 \\
\hline & $30-39$ years & 121 & 32.6 \\
\hline & $40-49$ years & 122 & 32.9 \\
\hline & 50 above & 75 & 20.2 \\
\hline \multirow[t]{6}{*}{ Education Level } & Doctoral & 7 & 1.9 \\
\hline & Master & 23 & 6.2 \\
\hline & Bachelor Degree & 212 & 57.1 \\
\hline & Diploma & 68 & 18.3 \\
\hline & High Secondary & 55 & 14.8 \\
\hline & Others & 6 & 1.6 \\
\hline Total & & 371 & 100.0 \\
\hline
\end{tabular}

\subsection{Sampling Procedure}

Stratified sample random technique was used in this study. Questionnaires were distributed hand to hand to the target employees from the ministries of Yemen's public sector namely Ministry of Finance, Ministry of Education, Ministry of Health and Ministry of Public Work and Highway which they are undergoing change. Their participation in the study was voluntary and confidentially treated as promised only for academic purpose. Furthermore, Participants were given surveys contain two sector firstly the responded profile section following by variable section which proposed to examined the level the participator agreement or vs versus about the normative commitment to change, leadership style and the organizational culture.

\subsection{Measurement}

The survey was developed based on previous studies (B.J. Avolio \& Bass, 2004; Glaser, Zamanou, \& Hacker, 1987; Herscovitch \& Meyer, 2002; Schrodt, 2002). Table 5 summarizes the reliability test of the measures. The Cronbach's Alphas of the measures were all comfortably above the lower limit of acceptability $(\alpha>.50)$, hence, all the measures were highly reliable (Cavana, Delahaye, \& Sekaran, 2001; Sekaran, 2009).

Table 2. Summary of variables measurement

\begin{tabular}{llll}
\hline Variable & Number of items & Coefficient Alpha & Authors \\
\hline Normative commitment to change & 6 & .93 & Herscovitch and Meyer (2002) \\
Transformational leadership & 20 & .91 & Bass, B.M. and Avolio, B.J. (2004) \\
Transactional leadership & 12 & .88 & Bass, B.M. and Avolio, B.J. (2004) \\
Organizational culture & 35 & .95 & Glaser, Zamanou and Hacker (1987) \\
\hline
\end{tabular}

The questionnaire contained five-point Likert scales, which anchored at "1"= Strongly Disagree to " 5 "=Strongly Agree, specific to measure the "employee commitment to change" and "organisational culture". Whereas, " 1 "=Not at All, ' $2 "=$ Once in a While, " $3 "=$ Sometimes, " $4 "=$ Fairly Often, " 5 '=Frequently if not Always, were used for the "leadership style". Table 2 shows the measurements of each variable in the questionnaire.

\subsection{Factor Analysis}

The factor analysis was based on principal component analysis (PCA) with Varimax rotation for all components. The Kaiser-Meyer-Olkin Measures of Sampling Adequacy value of 0.927 exceeded the recommended value of 
0.50 as a practically significant loading factor(Hair, Black, Babin, Anderson, \& Tatham, 2010). Bartlett's Test of Sphericity was also highly significant (chi square $=18519.163, p=.00$ ). Even though all the items were loaded clearly with an acceptable range, one item did not meet the requirements (18) and has been excluded for the further analysis.

Table 3. KMO and Bartlett's test

\begin{tabular}{ll}
\hline Eigenvalue & 12.271 \\
$\%$ of variance & 33.240 \\
Cronbach's Alpha $(\boldsymbol{\alpha})$ & .967 \\
Kaiser-Meyer-Olkin Measures of Sampling Adequacy & 0.927 \\
Bartlett's Test of Sphericity: Approx Chi-Square & 18519.163 \\
df & 2211 \\
Sig & .00 \\
\hline
\end{tabular}

This factor captured 33.24 percent of the total variance in the items. The reliability (Cronbach's Alpha) for these factors was .967 , which indicates high reliability.

\subsection{Data Analysis}

This study conducted data analysis and hypotheses testing using several statistical tools and methods which were employed from SPSS software, which include Descriptive statistics (frequency, means, standard deviations, reliability, and inter correlations). Factor and reliability analyses to test the goodness of measures, descriptive statistics to describe the characteristic of respondents, correlation analysis to describe the inter correlation among the variables, and to measure the significant of linear bivariate between the variables (Coakes, 2005). In addition, hierarchical multiple regression analysis was used to achieve the objective with testing the hypothesis.

\section{Finding}

\subsection{Descriptive Analysis}

Descriptive statistics, coefficient alpha reliabilities and correlations for the variables used in the current study were shown in table 4 . All scale reliabilities exceeded the 0.70 value recommended by (Hair, et al., 2010).

The results indicated that there was a significant and positive correlations between the transformational leadership and normative commitment to change variables $\left(\mathrm{r}=.540^{* *}\right)$. Following by transactional leadership was a significant and positive correlated with normative commitment to change variables $\left(\mathrm{r}=.577^{* *}\right)$. Finally, organizational culture was also a significant and positive correlated with normative commitment to change variables $\left(\mathrm{r}=.765^{* *}\right)$, which this indicated that organizational culture is quasi moderated the relationship between the variable.

Table 4. Means, standard deviations, reliability coefficients, and correlations

\begin{tabular}{lllllll}
\hline Variables & Mean & Std deviation & Alpha & $\mathbf{1}$ & $\mathbf{2}$ & $\mathbf{3}$ \\
\hline Normative & 3.350 & 0.820 & .927 & & & \\
Transformational & 3.883 & 0.464 & .901 & $.540^{* *}$ & & \\
Transactional & 3.883 & 0.464 & .877 & $.577^{* *}$ & $.614^{* *}$ & $.724^{* *}$ \\
Organizational culture & 3.595 & 0.546 & .953 & $.765^{* *}$ & $.652^{* *}$ &
\end{tabular}

Note: ** Correlation is significant at the 0.01 level (2-tailed).

Table 4 presents the summary of the relationships between the variables. In general, the table shows that there were significant and positive relationships between transformational, transactional leadership, organizational culture, and normative commitment to change, and the range was 0.540 to 0.765 , which indicate moderated to moderately high correlation.

\subsection{Testing of Hypotheses}

The first order in table 5 model 1 illustrates the relationship between the independent variables transformational and transactional leadership and employee normative commitment to change. The beta value of transformational leadership was .298 , and the beta value of transactional leadership was .395 with R square .338 . which that indicate that transformational leadership and transactional leadership were significant related to normative commitment to change with concern of transactional leadership shows that it has greater effect on normative 
commitment to change rather than transformational leadership. In this step these factors explain about 39 percent of variance of employee normative commitment to change.

Table 5. Summary of hierarchical regression analysis

\begin{tabular}{llll}
\hline Variables & Step 1 & Step 2 & Step 3 \\
\hline & B & B & B \\
Transformational Leadership & .298 & .064 & -.007 \\
Transactional Leadership & .395 & .030 & -.128 \\
Organizational Culture & & .702 & .456 \\
Transformational Leadership *Organizational Culture & & .146 \\
Transactional Leadership *Organizational Culture & & & .293 \\
\hline R square & .388 & .589 & .591 \\
Adjusted R square & .385 & .585 & .585 \\
R square changed & .388 & .200 & .002 \\
F & 116.892 & 175.168 & 105.291 \\
F Change & 116.892 & 178.779 & .784 \\
Std. Error of the Estimate & .64265 & .52770 & .52801 \\
Durbin-Watson & 1.813 & & \\
\hline
\end{tabular}

Notes: $\beta=$ Beta coefficient; IV=Transformational and transactional leadership; $M V=$ organizational Culture; DV=Employee Normative commitment to change.

Continuously, the second step the beta value of transformational leadership was .064 and transactional leadership at .030 and the moderating variable organizational culture was .702. This finding indicated that the moderating variable is significantly related to the normative commitment to change with $\mathrm{R}^{2} .589$. Furthermore, it can be conclude that with including the moderating variable in the relation the independent variables can have greater effect on dependent variable and can explain 59 percent of the variance.

Finally, the third step, the finding shows the $\mathrm{R}^{2}$ change of interaction effect was .002, which means the moderating effect of organizational culture between the leadership style and employee normative commitment to change was small based on the (Cohen, 1988), at $\mathrm{R}^{2}$ change $=.002$ small, .15 medium, and .35 large. Therefore, it can be concluding that the transformational and transactional leadership were significantly related to normative commitment to change and organizational culture was quasi moderated this relation. In sum of that, all hypotheses H1-H4 were confirmed, and the following figures for more illustrated about the moderating effect.

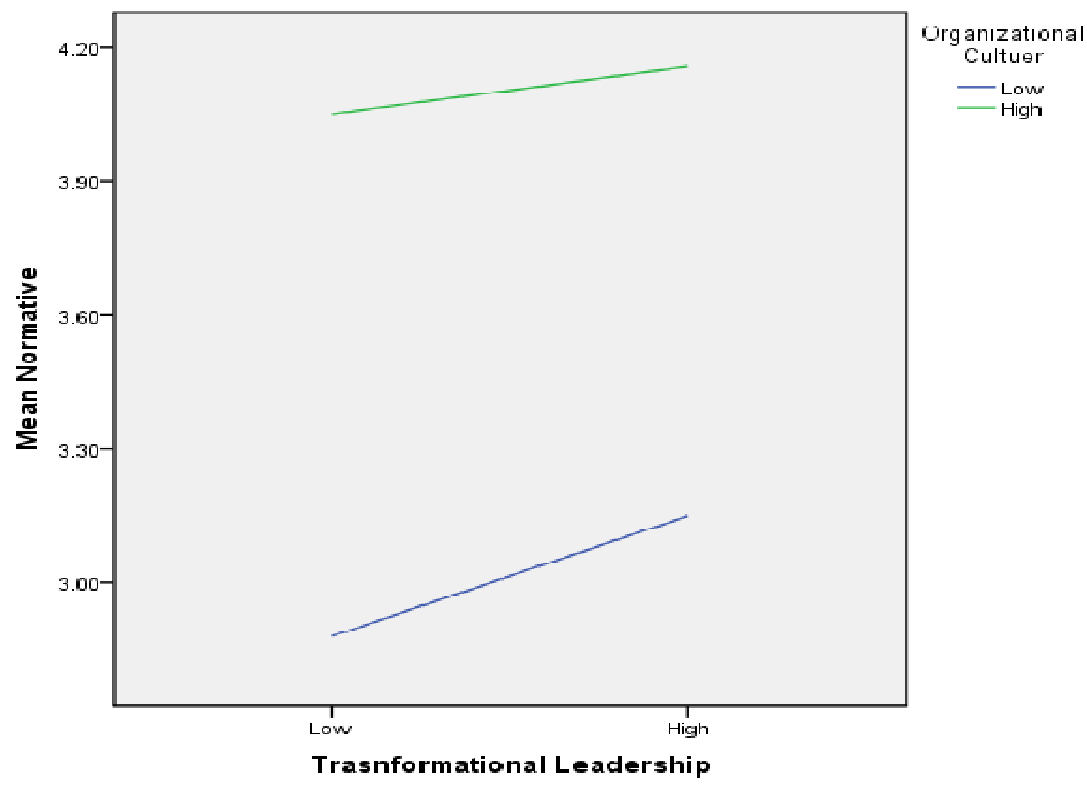

Figure 2. Moderating effect of organizational culture between transformational leadership and normative commitment to change 


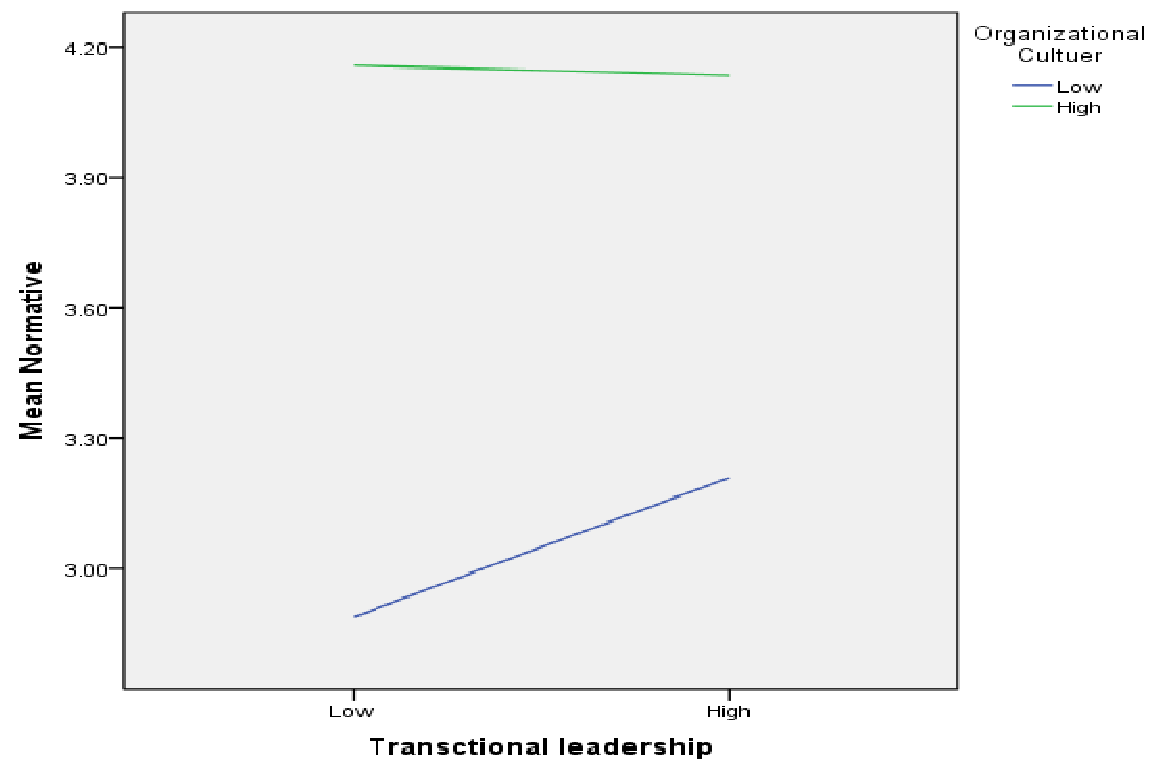

Figure 3. Moderating effect of organizational culture between transactional leadership and normative commitment to change

\section{Discussion}

The main objective of this study was to examine the moderating effect of organizational culture between the leadership style namely transformational and transactional and employee normative commitment to change. The finding shows that transformational leadership has positive significant relationship with normative commitment to change. It is clear that transformational leadership is one of the key factors of enhancing the normative commitment to change especially in the context of this study. Without neglecting the importance of organizational culture in term of moderated this relation. Furthermore, the finding of this study was confirmed the hypotheses which stated as there is a significant relationship between transformational leadership and normative commitment to change and organizational culture is significantly moderated the relationship between transformational leadership and employee normative commitment to change. Based on this unique finding the Yemeni employees deal positively with change, once they have good and effective leader without forgotten the motivation factor. Thus, the leader behavior is an essential factor among Yemeni subordinators. In this regard, transformational leadership organizational culture style were enhanced the normative commitment among employee, and it was in line with previous studies such as (Herold, et al., 2008), (Lo, et al., 2010 ), and (Yu, Leithwood, \& Jantzi, 2002) who viewed transformational leadership as having a positive relationship with employee commitment to change. In addition, the Yemeni public sector organizations should train leaders how to delegate authority with a focus on the individual consideration as well as other factors of transformational leadership if they are looking for employees to become more effectively.

The finding also shows that transactional leadership has positive and significant relationship with employee normative commitment to change and considered as a crucial predictor in term of enhancing the Yemeni employee's normative commitment to change. This empirical finding has confirmed the hypothesized relationship and is consistent with findings of previous studies such as (Lo, et al., 2009), (Vecchio, Justin, \& Pearce, 2008), (Marmaya, Hitam, Torsiman, \& Balakrishnan, 2011). The Yemeni employee was highly responsive to transactional leadership behavior because they prefer to work with clear vision especially with reward and motivation base. The Bass's model theory clarified on the earlier stage that transactional leadership is based on exchange task and reward between leader and subordinates. Thus, the Yemeni subordinates since they are not satisfy and lack of commitment, they willingness to work with an obvious approach rather than ambiguity and preoccupied of reward system.

In term of the moderating effect of organizational culture, although a considerable number of researchers have argued that there is a constant interplay between organizational culture and leadership, there are limited empirical studies examining the relation between leadership and culture as well as their joint effect on important organizational outcomes (Schimmoeller, 2010; Trice \& Beyer, 1993; Yiing \& Ahmad, 2009). However, (Yiing \& Ahmad, 2009) studied the moderating effect of organizational culture on the relationship between leadership 
style and organizational commitment, and they found that organizational culture played an important role of moderating the effect among these two constructs. Other researchers have also indicated that harmonious combination of appropriate leadership behaviors with certain types of organizational cultures could positively influence employees' performance (Hickman \& Silva, 1984; Ogbonna \& Harris, 2002). Similarly under these streams of researchers are (Lok \& Crawford, 2004) that studied the effect of different leadership behaviors on organizational commitment as a contingent upon organizational culture. Therefore, the empirical finding shows that organizational culture is moderated the relationship between the transformational and transactional leadership style and normative commitment to change in Yemeni context. This leads to the importance of the organizational culture among Yemeni employees and shows the importance of organizational culture beside the leadership style in term of enhancing the normative commitment to change. Therefore, understanding the culture is very crucial factor of successfully implement any change.

\section{Conclusions, Limitations and Future Research}

\subsection{Summary of Finding}

As organization struggle to be developed, there is a pressure which requires then to understand the factors that may directly or indirectly affect people behaviors' in organizations. However, this study was concerned with two important issues in the field of organizational change, leadership and employee normative commitment to change as well as organizational culture. The literature revealed that both subjects were considered as major contributors to the success of any change. In addition, the findings of this study indicated that transformational and transactional leadership styles were significant and positively related to the employee normative commitment to change. Additionally, the findings showed that the organizational culture was moderated the relationship between the leadership style and employee's normative commitment to change.

\subsection{Limitation and Directions for Future Research}

Based on the researcher's observations, this study is considered the first study to examine the relationship between leadership style and employee commitment to change with organizational culture as a moderating variable. It has a number of inherent limitations. Firstly, data collection was done cross-sectional; therefore, future study may look into a longitudinal study in order to expand the findings that are the pre- and post-changes. Secondly, this study concerns on public sector. Thus, future study may concerns in other sectors. It is good to look into another critical factor that may enhance the employee commitment to change such as, motivation, training, job satisfaction, job justice, empowerment, readiness of change, change involvement as well awareness of the value of the change and might another leadership style. Last but not least, this study concern only on normative commitment to change whereas commitment to change has three dimensions which is affective, continuous, and normative, so it is interesting to study all dimensions of employee commitment to change as well as to examine them with the dimensions of transformational and transactional leadership since this study also concern only on construct.

\subsection{Implication and Conclusion}

The findings of this study have practical implications for public sector organizations. The study found several statistically significant relationships with practical applications. Public sector organizations that are interested in implementing change must be concerned with leadership style and organizational culture as well as with normative commitment to organizational change. To increase the probability of normative commitment to change in public sector organizations, transactional leadership is considered a better predictor than is transformational leadership, because employees feel slightly less obligated to support a change initiated by this type of leadership style. Finally, this study provides a guideline for the public sector in Yemen to achieve effective and efficient leadership and normative commitment to change, which can lead to successful change implementation. Finally, with intend to have better performance and high commitment to change in public sector in Yemen; it is requiring having motivation and rewarding system. Without doubt, absence of motivation and appropriate and effective leader, will definitely lead to lack of commitment to change, and efficacy and efficiency among the subordinates. In conclude that, leadership style and employee commitment change is still vague and need further attention as well as organizational culture.

\section{Acknowledgments}

We are grateful to the Almighty Allah for giving us strength to complete the study. May peace and blessing of Allah be upon His beloved Prophet Muhammad (SAW), his family and his companions. We owe a debt of gratitude and thanks to all the respondents and participants of this study who gave us their support and commitment. 


\section{References}

Ahmad, H., Francis, A., \& Zairi, M. (2007). Business process reengineering: critical success factors in higher education. Business Process Management Journal, 13(3), 451-469. http://dx.doi.org/10.1108/14637150710752344

Ahmad, H., \& Gelaidan, H. M. (2011). Organisational Culture, Leadership Styles and Employee's Affective Commitment to Change: A Case of Yemen Public Sector. Journal of Organizational Management Studies.

Argyris, C., \& Schon, D. A. (1978). Organizational Learning: A Theory of Action Perspective. Reading.

Avolio, B. J., \& Bass, B. M. (2002). Developing potential across a full range of leadership: Cases on transactional and transformational leadership. Mahwah, NJ, US: Lawrence Erlbaum Associates Publishers.

Avolio, B. J., \& Bass, B. M. (2004). Multifactor Leadership Questionnaire (MLQ). Mind Garden.

Bass, B. M. (1985). Leadership: Good, Better, Best. Organizational Dynamics, 13(3), 26-40. http://dx.doi.org/10.1016/0090-2616(85)90028-2

Bass, B. M., \& Avolio, B. J. (1994). Improving Organizational Effectiveness Through Transformational Leadership. Sage Publications Inc.

Bass, B. M., \& Riggio, R. E. (2006). Transformational leadership. Lawrence Erlbaum.

Battilana, J., Gilmartin, M., Sengul, M., Pache, A. C., \& Alexander, J. A. (2010 ). Leadership competencies for implementing planned organizational change. The Leadership Quarterly, 21(3), 422-438. http://dx.doi.org/10.1016/j.leaqua.2010.03.007

Burke, W. W. (2002). Organization Change: Theory and Practice. Sage Pubns.

Burnes, B. (2004). Kurt Lewin and the Planned Approach to Change: A Re-appraisal. Journal of Management Studies, 41(6), 977-1002. http://dx.doi.org/10.1111/j.1467-6486.2004.00463.x

Burns, J. M. G. (1978). Leadership. Harper \& Row New York.

Bycio, P., Hackett, R. D., \& Allen, J. S. (1995). Further assessments of Bass's (1985) conceptualization of transactional and transformational leadership. Journal of Applied Psychology, 80(4), 468-478. http://dx.doi.org/10.1037/0021-9010.80.4.468

Cavana, R., Delahaye, B., \& Sekaran, U. (2001). Applied business research. Brisbane Qld: Wiley.

Coakes, S. J. (2005). SPSS: Analysis without anguish: Version 12.0 for Windows. Wiley.

Cohen, J. (1988). Statistical power analysis for the behavioral sciences. Lawrence Erlbaum.

Conway, E., \& Monks, K. (2008). HR practices and commitment to change: an employee-level analysis. Human Resource Management Journal, 18(1), 72-89. http://dx.doi.org/10.1111/j.1748-8583.2007.00059.x

Cunningham, G. B. (2006). The relationships among commitment to change, coping with change, and turnover intentions. European Journal of Work \& Organizational Psychology, 15(1), 29-45. http://dx.doi.org/10.1080/13594320500418766

Elias, S. M. (2009). Employee Commitment in Times of Change: Assessing the Importance of Attitudes Toward $\begin{array}{lllll}\text { Organizational } \quad \text { Change. Journal } & \text { 37-55. }\end{array}$ http://dx.doi.org/10.1177/0149206307308910

Glaser, S. R., Zamanou, S., \& Hacker, K. (1987). Measuring And Interpreting Organizational Culture. Management Communication Quarterly: McQ (1986-1998), 1(2), 173.

Hair, J. F., Black, B., Babin, B., Anderson, R. E., \& Tatham, R. L. (2010). Multivariate Data Analysis: A Global Perspective. New Jersey, USA: Pearson Education Inc.

Herold, D. M., Fedor, D. B., Caldwell, S., \& Liu, Y. (2008). The effects of transformational and change leadership on employees' commitment to a change: A multilevel study. Journal of Applied Psychology, 93(2), 346-357. http://dx.doi.org/10.1037/0021-9010.93.2.346

Herold, D. M., Fedor, D. B., \& Caldwell, S. D. (2007). Beyond change management: A multilevel investigation of contextual and personal influences on employees' commitment to change. Journal of Applied Psychology, 92(4), 942-951. http://dx.doi.org/10.1037/0021-9010.92.4.942

Herscovitch, L., \& Meyer, J. P. (2002). Commitment to organizational change: Extension of a three-component model. Journal of Applied Psychology, 87(3), 474-487. http://dx.doi.org/10.1037/0021-9010.87.3.474 
Hickman, C. R., \& Silva, M. A. (1984). Creating excellence: managing corporate culture, strategy, and change in the New Age. New American Library New York.

Hofstede, G. (2005). Cultures and organizations: Software of the mind (Vol. 23). McGraw-Hill.

Howarth, M. D., \& Rafferty, A. E. (2009). Transformational Leadership And Organizational Change: The Impact Of Vision Content And Delivery. Academy of Management Proceedings, 1-6.

Huq, Z., \& Martin, T. N. (2001). Workforce Cultural Factors in TQM/CQI Implementation in Hospitals. Quality Management in Health Care, 9(2), 43.

Ismail, A., Mohamad, M. H., Mohamed, H. A. B., Rafiuddin, N. M., \& Zhen, K. W. P. (2010). Transformational and Transactional Leadership Styles as a Predictor of Individual Outcomes. Theoretical \& Applied Economics, 17(6), 89-104.

Kavanagh, M. H., \& Ashkanasy, N. M. (2006). The Impact of Leadership and Change Management Strategy on Organizational Culture and Individual Acceptance of Change during a Merger. British Journal of Management, 17, S81-S103. http://dx.doi.org/10.1111/j.1467-8551.2006.00480.x

Kotter, J. P. (1995). Leading Change: Why Transformation Efforts Fail. (cover story). Harvard Business Review, 73(2), 59-67.

Kotter, J. P. (1996). Leading Change. Harvard Business School Press.

Krejcie, R. V., \& Morgan, D. W. (1970). Determining sample size for research activities. Educational and Psychological Measurement, 30(3), 607-610.

Lo, M. C., Ramayah, T., de Run, C., \& Voon, M. L. (2009). "New Leadership”, Leader-Member exchange And Commitment To Change: The Case Of Higher Education In Malaysia.

Lo, M. C., Ramayah, T., \& Run, E. C. D. (2010). Does transformational leadership style foster commitment to change? The case of higher education in Malaysia. Procedia - Social and Behavioral Sciences, 2(2), 5384-5388.

Lok, P., \& Crawford, J. (2004). The effect of organisational culture and leadership style on job satisfaction and organisational commitment: A cross-national comparison. Journal of Management Development, 23(4), 321-338. http://dx.doi.org/10.1108/02621710410529785

Marmaya, N., Hitam, M., Torsiman, N. M., \& Balakrishnan, B. (2011). Employees' perceptions of Malaysian managers' leadership styles and organizational commitment. African Journal of Business Management, 5(5), 1584-1588.

Martin, J. (2002). Organizational Culture: Mapping the Terrain. Sage Publications Inc.

Martins, L. (2008). Organizational development and change.

Meyer, J. P., \& Allen, N. J. (1997). Commitment in the workplace: Theory, research, and application. Sage Publications, Inc.

Meyer, J. P., \& Herscovitch, L. (2001). Commitment in the workplace: Toward a general model. Human Resource Management Review, 11, 299-326. http://dx.doi.org/10.1016/S1053-4822(00)00053-X

Meyer, J. P., Srinivas, E. S., Lal, J. B., \& Topolnytsky, L. (2007). Employee commitment and support for an organizational change: Test of the three-component model in two cultures. Journal of Occupational \& Organizational Psychology, 80(2), 185-211. http://dx.doi.org/10.1348/096317906X118685

Meyer, J. P., Stanley, D. J., Herscovitch, L., \& Topolnytsky, L. (2002). Affective, continuance, and normative commitment to the organization: A meta-analysis of antecedents, correlates, and consequences. Journal of Vocational Behavior, 61(1), 20-52. http://dx.doi.org/10.1006/jvbe.2001.1842

Narine, L., \& Persaud, D. D. (2003). Gaining and maintaining commitment to large-scale change in healthcare

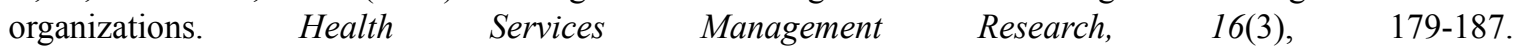
http://dx.doi.org/10.1258/095148403322167933

Neuhauser, C. (1999). The Ancestral Graph and Gene Genealogy under Frequency-Dependent Selection. Theoretical Population Biology, 56(2), 203-214. http://dx.doi.org/10.1006/tpbi.1999.1412

Ogbonna, E., \& Harris, L. C. (2002). Organizational Culture: A ten Year, Two - phase Study of Change in the UK Food Retailing Sector. Journal of Management Studies, 39(5), 673-706. http://dx.doi.org/10.1111/1467-6486.00004 
Parish, J. T., Cadwallader, S., \& Busch, P. (2008). Want to, need to, ought to: Employee commitment to organizational change. Journal of Organizational Change Management, 21(1), 32-52. http://dx.doi.org/10.1108/09534810810847020

Porter, L. W., Steers, R. M., Mowday, R. T., \& Boulian, P. V. (1974). Organizational Commitment, Job Satisfaction, And Turnover Among Psychiatric Technicians. Journal of Applied Psychology, 59(5), 603-609. http://dx.doi.org/10.1037/h0037335

Schimmoeller, L. J. (2010). Leadership Styles in Competing Organizational Cultures.

Schrodt, P. (2002). The Relationship Between Organizational Identification And Organizational Culture: Employee Perceptions Of Culture And Identification In A Retail Sales Organization. Communication Studies, 53(2), 189. http://dx.doi.org/10.1080/10510970209388584

Sekaran, U. (2009). Research methods for business: A skill building approach. Wiley-India.

Shum, P., Bove, L., \& Seigyoung, A. (2008). Employees' affective commitment to change The key to successful CRM implementation. European Journal of Marketing, 42(11/12), 1346-1371. http://dx.doi.org/10.1108/03090560810903709

Silverthorne, C. (2004). The impact of organizational culture and person-organization fit on organizational commitment and job satisfaction in Taiwan. Leadership \& Organization Development Journal, 25(7), 592-599. http://dx.doi.org/10.1108/01437730410561477

Sosik, J. J., \& Dionne, S. D. (1997). Leadership Styles And Deming'S Behavior Factors. Journal of Business \& Psychology, 11(4), 447-462. http://dx.doi.org/10.1007/BF02195891

Svensen, E., Neset, G., \& Eriksen, H. R. (2007). Factors associated with a positive attitude towards change among employees during the early phase of a downsizing process. Scandinavian Journal of Psychology, 48(2), 153-159. http://dx.doi.org/10.1111/j.1467-9450.2007.00577.x

Trice, H. M., \& Beyer, J. M. (1993). The cultures of work organizations. Englewood Cliffs, NJ US: Prentice-Hall, Inc.

Vecchio, R. P., Justin, J. E., \& Pearce, C. L. (2008). The utility of transactional and transformational leadership for predicting performance and satisfaction within a path-goal theory framework. Journal of Occupational \& Organizational Psychology, 81(1), 71-82. http://dx.doi.org/10.1348/096317907X202482

Vestal, K. W., \& Fralicx, R. D. (1997). Organizational culture: The critical link between strategy and results. Hospital \& Health Services Administration, 42(3), 339.

Westover, J. H. (2010). Managing Organizational Change: Change Agent Strategies and Techniques to Successfully Managing the Dynamics of Stability and Change in Organizations. International Journal of Management \& Innovation, 2(1), 45-50.

Yiing, L. H., \& Ahmad, K. Z. B. (2009). The moderating effects of organizational culture on the relationships between leadership behaviour and organizational commitment and between organizational commitment and job satisfaction and performance. Leadership \& Organization Development Journal, 30(1), 53-86. http://dx.doi.org/10.1108/01437730910927106

Yu, H., Leithwood, K., \& Jantzi, D. (2002). The effects of transformational leadership on teachers' commitment to change in Hong Kong. Journal of Educational Administration, 40(4/5), 368. http://dx.doi.org/10.1108/09578230210433436 